\title{
THE CATHOLIC BUILDING PROFESSIONAL ADVISORY GROUP AND ITS SPIRITUALITY
}

\author{
Laity Involvement in Church Building System of the Catholic Diocese of Hong Kong \\ 天主教建築專業諮詢小組とそのスピリチュアリティ \\ カトリック香港教区の教会堂建設システムにおける一般信徒参画
}

\section{Ayako FUKUSHIMA* and Yoshitake DOI**}

福島綾子, 土居義岳

\begin{abstract}
Catholic Building Professional Advisory Group (CaBPAG) was established in 2006 under Diocesan Building and Development Commission of the Catholic Diocese of Hong Kong. The CaBPAG was called for to assist building and maintenance of church and related facilities by involving the volunteer laity of building professionals. This study revealed that the laity integrated the spiritual activities and professional contribution in building projects within the CaBPAG. Such pursuit of spirituality can be understood within the context of worldwide development of spirituality since the 1960s and the local context of Hong Kong such as endangered religious freedom.
\end{abstract}

\section{Keywords : Catholic, Church building, Laity, Involvement, Spirituality, Hong Kong \\ カトリック，教会堂，一般信徒，参画，スピリチュアリティ，香港}

\section{Objective of the Study}

The authors have studied the development process of involvement of the laity in the church building projects in the Catholic Diocese of Hong Kong (the Diocese) within the framework of lay apostolate/lay ministry presented in the Second Vatican Council(Vatican II). ${ }^{1}$ First, the authors studied the Diocesan Building and Development Commission (DBDC) established in 1995. It was set up in collaboration between the laity and the clergy for the purpose to assist the clergy in the Diocesan building projects. ${ }^{2)}$ Then, the authors revealed the actual involvement of the laity and the clergy in the planning and designing of a church with the case study of Our Lady of Mount Carmel Church. ${ }^{3)}$ We interpreted the laity involvement within the three contexts: 1. the anticipated restriction on the religious freedom after the handover of Hong Kong to China; 2. search of identity as Hong Kong citizens or Catholics; 3. the shift to the governance approach of the Diocese as the consequence of maturation of the Hong Kong society and citizens. ${ }^{4)}$ This paper studies the "Catholic Building Professional Advisory Group (CaBPAG)"(fig.1). It was established in 2006 as a sub-group of the DBDC. The author has conducted archival research and interviews with the laity and the clergy of the DBDC and the CaBPAG between 2008 and 2014.
Especially in 2012, the authors observed that the CaBPAG was formed as the result of the pursuit of spirituality by the laity.

The authors identify the CaBPAG as the combination of two different aspects:

1. Insufficiency of the DBDC's human resources in assisting the parishes' building and maintenance issues necessitated a supplemental organization;

2. The laity were keen to foster their communal spirituality, hence, formed the organization for spiritual activities.

Based on those aspects, the authors aim to examine the CaBPAG's background, objectives, organizational structure, and activities, and reveal how the laity integrate building and maintenance projects with spirituality.

\section{CaBPAG as a Building and Maintenance Organization}

\subsection{Maintenance issues at parishes}

It was the tradition for parishes of Hong Kong Catholic Church to be responsible for the maintenance of their own church buildings and other facilities. Such a situation remained unchanged for a while even after the establishment of the DBDC in 1995. However, the requests for help from the parishes to the DBDC increased in the 21st century. The DBDC was well

\footnotetext{
* Assistant Prof., Faculty of Design, Kyushu University, M. Sci. in Historic Preservation九州大学大学院芸術工学研究院 助教 ·修士 (科学)

** Prof., Faculty of Design, Kyushu University, Dr. Eng. 


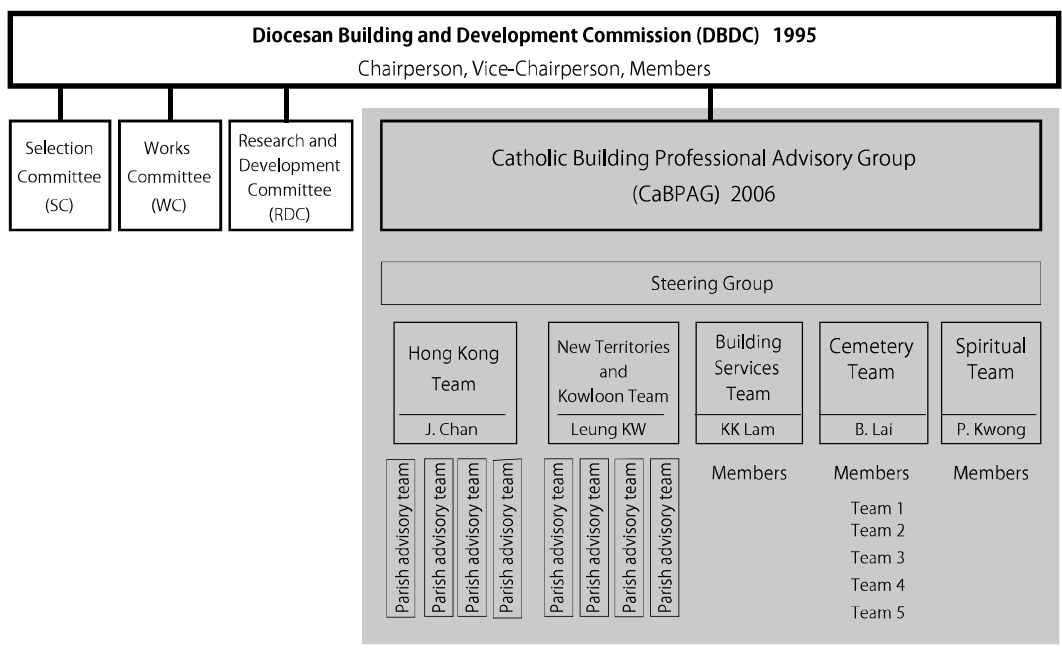

Fig. 1 Organizational Structure of DBDC and CaBPAG

aware by 2004 that the independent maintenance by the parishes became unsustainable. ${ }^{5)}$ Due to the limited number of the DBDC staff and a large number of parishes, it took a very long time for the DBDC to respond to each request from a parish. ${ }^{6)}$

\subsection{Priest Workshop}

In January, 2005, the Diocesan Committee for the Ongoing Formation of the Clergy, in collaboration with the DBDC, held the workshop "Effective Management Operation Model for Parishes"(WS) for the clergy serving in the Diocese. Themes included "Building Management and Maintenance," "Building Maintenance and Renovation," "Legal responsibilities of Church/ Building Premises as landlord or occupier," and "Liturgical aspects in building maintenance and renovation." "I) In this WS, the clergy raised the issues such as "escalating cost of electricity yearly," "improve the audio/ lighting systems in the older churches," and procedures to be taken for renovation of church and Catholic schools. ${ }^{8}$ The DBDC felt the necessity of a group of the professional laity at the Diocesan level to support the parishes while maintaining the independency of the parishes. ${ }^{9)}$

\subsection{Catholic engineers' association as the predecessor}

Since the late 1990s, the engineers, Paul Tam, M.T. Chow, and two more, all parishioners of the Cathedral, as well as Raymond Shiu of another parish, had been planning to set up a Catholic engineers' association to advise the clergy on the facility maintenance. They were especially inspired by the setup of a Diocesan Commission for the Health Care of The Clergy and Religious in 2004. ${ }^{10)}$ Catholic engineers' association remained as an idea for some years. The details of the initial idea of this association are described in the Chapter 3.

\subsection{Further development and materialization at the Research and De-} velopment Committee

The WS was concerned about the facility maintenance of the parishes.

The above mentioned Raymond Shiu, around January 2005, as a member of the Research and Development Committee (RDC), which is one of the sub-committees of the DBDC, in relation with the concerns raised in the WS, mentioned at the RDC meeting that he and other colleagues had been discussing an idea to set up the engineers' association (fig.1). ${ }^{11)}$ Shiu was one of the key persons in defining the mission and objectives, which is detailed in the Chapter 3.

Dominic Chan, Vicar General of the Diocese, prompted the laity to develop and materialize the mission and objectives. He was the member of the DBDC and the RDC, as well as the chairperson of the Diocesan Commission for the Health Care of The Clergy and Religious, and Diocesan Commission for Laity Formation until 2004 respectively. In addition, since his appointment as the Vicar General in 1992, he has been looking after matters related to all parishes. Through such services, he had realized that in the past 10 years since the DBDC's establishment, the lay members had been working hard and it was good, but there should be something more in spiritual dimension. Hence, having also considered the necessity to support the parishes, the priests' feedback in the WS, and the idea of engineers' group, D. Chan proposed that a new group, suggested by R. Shiu, could be composed of the volunteer professional laity such as engineers, architects, and building services engineers, to assist the DBDC in supporting the parishes, the deaneries and the Diocese, and at the same time to pursue spiritual growth of the members. ${ }^{12)}$ This idea by D. Chan, bringing two different streams together, was favored and incorporated by the RDC members.

From February, 2005, the RDC discussed the organizational structure, the official name, concrete activities for the association. ${ }^{13)}$ The association's role is defined to be advisory, and the activities include spiritual ones. ${ }^{14}$

\subsection{The Preparatory Committee}

The Preparatory Committee was set up on June $9^{\text {th }}, 2005$. The members of this committee included Simon Li, who was the chairperson of the DBDC, Maurice Lee, Philip Kwok, Leung Kingwai, SL Lam, Teresa Chu, Bosco Fung, Bernard Lai, John Wong, Ken Lam, who were the DBDC members, and Brendan Yeung and Raymond Shiu as the RDC members as well as J. Chan and Gabriel Lam. ${ }^{15)}$

The important matters were agreed to in the meeting held on September $5^{\text {th }}, 2005$. The name of the association was decided to be "Catholic Building Professional Advisory Group"(CaBPAG). Spirituality proposed by Gabriel Lam was examined and accepted. ${ }^{16)}$

The CaBPAG was officially established under the DBDC in May, 2006. ${ }^{17}$ )

\subsection{Steering Group}

Preparatory Committee was re-organized as the Steering Group $(\mathrm{SG})$ of the 
CaBPAG. ${ }^{18)}$ It assumes overall co-ordination for reporting to the DBDC. ${ }^{19)}$

\subsection{Working Guidelines}

Upon the official establishment of the CaBPAG in 2006, the SG launched a team to compile "Working Guidelines for Members." The team members had been drafting and revising it until 2011, when they officially made it available to all CaBPAG members as well as parishes. Contents of the guidelines are: Background, Mission and Objectives, Role and Function, Organization, Eligibility of Participants, Conduct and Conflict of Interests, Spiritual Activities, Communication along with Attachments of Guidance Notes for Liturgical Design(to be issued later), Property Maintenance, Procurement and Contractual Procedures, and Minor Works(to be issued later). ${ }^{20)}$

Texts for "Mission and Objectives," "Role and Function," "Organization," and "Eligibility of Participants" were already prepared by the official setup of the CaBPAG in 2006, and publicized in a leaflet, website, and other official documents since then.

\subsection{Membership}

The CaBPAG defines the eligibility of the membership as: "all Catholic and non-Catholic building and related professionals with corporate membership of relevant professional institutions or equivalent qualification are eligible to join. The list covers architects, engineers (including but not limiting to building, civil, electrical, electronics, mechanical, structural, geotechnical and building services), planners and surveyors, as well as building related experts and specialists (in lighting, acoustics, heritage and conservation, environment, design, landscaping and other relevant fields)."

A building professional, who is interested to join the CaBPAG, may self-nominate. The CaBPAG Convenor reports this application to the SG members, Procurator, and the DBDC Chairperson. The CaBPAG Convenor makes the final approval. ${ }^{22)}$

According to Simon Li and J. Chan, the CaBPAG is meant to pool the future members of the DBDC. Through participating in the CaBPAG, the members are expected to know more about the entire system of the DBDC, and contribute to it when they have more time in the future.

\subsection{Organizational Structure}

Working Guidelines defines that "the primary role of the CaBPAG is to provide professional advice to the Diocese on Church premises, building, engineering, development and related matters including property and building management, maintenance and improvement, compliance with government regulations and requirements, construction contracts and liability issues. The services provided would be purely advisory and on a need-basis, without compromising the functions of existing set-ups at the DBDC Administration, deanery and parish levels." ${ }^{23}$

Upon the official setup of the CaBPAG, the following teams were formed: the Hong Kong Team, the Kowloon and New Territories Team, the Special Duties Team, the IT and Network Communication Team, the Training and Orientation Team, and the Guideline/Handbook Team. Latter four were reorganized, and the new teams were formed after a few years. The members are free to express their preferences and specialization in joining the teams. ${ }^{24)}$ Each team has a leader. The teams in operation as of October 2013 are described in the following sections (fig.1)
The column in table 1 illustrates all the past and present members of the Spiritual Team, and the CaBPAG members, who are/were not the Spiritual Team members, but participated in the Team's events as a coordinator or a speaker. The row shows the activities they have conducted as well as the membership in other teams.

\subsubsection{Hong Kong Team}

When a parish has a certain problem or issue, it consults with the DBDC. If it is a long-term and non-urgent project, then the DBDC entrusts the project to the Convenor of the CaBPAG. The Convenor assigns the project to the leader of a team according to the geographical location of the parish.

The leader forms an ad-hoc parish advisory team by selecting three team members, who are usually one architect, one building services engineer, and one structural engineer, out of the registered $\mathrm{CaBPAG}$ members in order to dispatch them to the parish. According to the demand of the project, the leader may select a member of another profession such as a civil engineer. ${ }^{25)}$

J. Chan has been the leader of Hong Kong Team since its establishment in 2006 until the present (2013 October). He usually appoints the architect as the team leader. In order to avoid the conflict of interest, he usually includes at least one public servant, who is also more flexible in terms of time availability. ${ }^{26)}$ He selects members, whose profession is suitable for the project, and either home or office is close to the project site. When possible, he tries to select a member, who actually belongs to the parish in need of the CaBPAG's assistance as a parishioner because the parishioners know the parish's needs better and are expected to be more devoted to the parish. He calls the candidate member directly and asks the person whether he/she has an interest to join the parish advisory team and has time to volunteer. He also tries to recruit members who have not yet participated in a parish advisory team when a new project comes up so that increasing number of members will have experiences.

The responsibilities of a parish advisory team are feasibility study and preparation of a client brief for installation or improvement of a lift, air conditioning, sound and audio-visual system, lighting as well as major renovation, expansion, compliance with government regulations, cost estimate, selection of a designer and/or contractor, and contractual arrangement.

The parish advisory team dissolves once the client brief is prepared. It does not take up tasks such as design, construction, consultancy or project management in design and construction stages. The DBDC together with the parish takes up execution and management of the project followed by and based on the CaBPAG's feasibility study. ${ }^{27)}$ The DBDC selects an architect or an engineer to make the schematic design and further develop it. The parish may set up a Task Force for the project to work with the DBDC and the architect/engineer. In some cases, one or more members of the CaBPAG advisory team is asked to join this Task Force and participate in the planning and design process.

\subsubsection{New Territories and Kowloon Team}

This team functions the same as the Hong Kong Team and governs the projects in the New Territories and Kowloon. The leader is Leung Kingwai. He often acts as the leader of the parish advisory team by himself. ${ }^{28)}$ 
Table 1 Members of the CaBPAG's Spiritual Team and their activities

indicates Spiritual Team member. Philip Kwok, Ken Lam and KK Lam, are not members of the Spiriatual Team, but have been speakers in seminars organized by the Team.

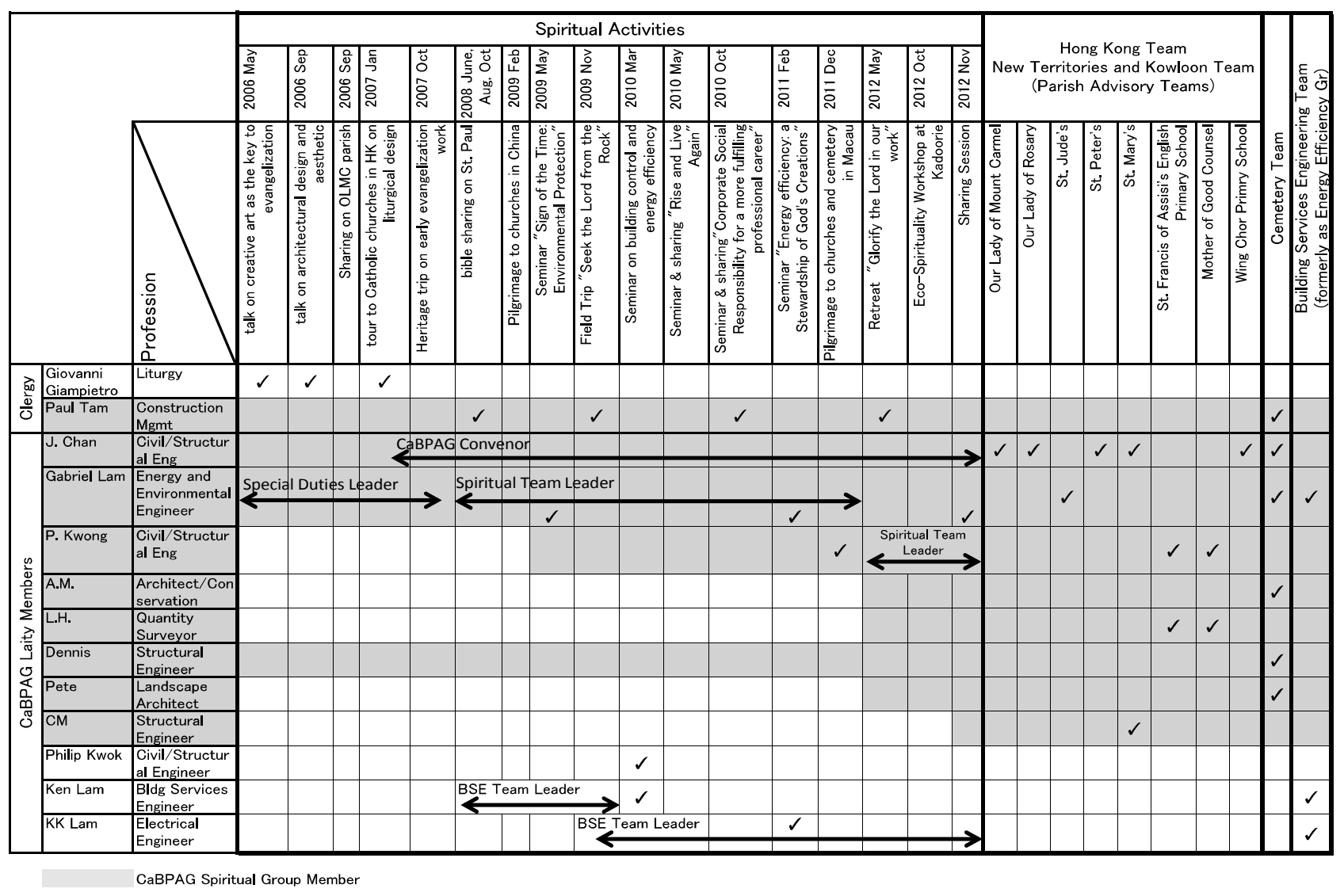

Philip Kwok, Ken Lam and KK Lam, who are not members of the Spiriatual Team, but have been speakers in seminars organised by the Team.

\subsubsection{Cemetery Team}

The Diocese owns five diocesan cemeteries. The Diocesan Board of Catholic Cemeteries (DBCC) has only one professional staff in charge of the hardware management and maintenance of all the diocesan cemeteries. Upon the request of the DBCC, the Cemetery Team was established in 2007 in order to take up the task of planning the effective use of the cemetery premises. The major activities of the Team are to plan and propose the improvement of the land use, facilities, circulations, landscape and tombstone design of the cemeteries. A sub-team of two members was formed for each cemetery(fig. 1).

\subsubsection{Building Services Engineering Team}

In 2008, the Energy Efficiency Group was set up to take up issues related to Building Energy Codes and Good Energy Performance for church premises. In 2012, it changed the group name to Building Services Engineering(BSE) Team to include all issues relating to building services engineering and not only to energy efficiency. ${ }^{29)}$

As of June, 2013, there are 11 members, of which eight are building services engineers, and others are an engineer of lift, an engineer of HVAC, and an energy and environmental consultant. ${ }^{30)}$

The activities implemented are: replacement of lighting of churches and other facilities to LED to become more energy efficient, the application for government funding scheme for energy efficiency, investigating the feasibility of the application of solar power to supply energy to CCTV and lighting for the cemetery, and the possibility of applying government subsidy for this project, in which the BSE Team collaborated with the Cemetery Team. ${ }^{31)}$ A code of practice was promulgated by the Hong Kong Government for implementation in September, 2012 for all "Government, Institution and Community" buildings (above 5,000 sq. ft) including electrical installations, $\mathrm{A} / \mathrm{C}$, lighting and escalators, at the same time an energy audit within one year would be required for buildings of 20 years old. To comply with this new regulation, the BSE Team members and J. Chan gave lectures on it to the parish priests. ${ }^{32)}$

\subsubsection{Spiritual Team}

The spiritual activities had been dealt by the Special Duties Team from 2006 until March 2008, then, taken over by the Spiritual Team.

The details of this team are examined in the following chapter.

\section{Spirituality and CaBPAG}

\subsection{Development of spirituality}

Spirituality in Christianity had been limited to the clergy and the religious from medieval time to the $1960 \mathrm{~s}$, and had little relevance to the laity. ${ }^{33)}$ However, since the 1960 s, spirituality became popularized and shared with not only the Catholic laity, but also the individuals, who were not associated with religious organizations.

Outside the Catholic Church, there arose the New Age in the U.S. and socalled "new spirituality movements and/or culture" as defined by Shimazono, in which people tended to be more individualistic and do not have a strong attachment to religious organizations. ${ }^{34)}$ Spirituality became popularized in 
the various spheres of the society, for example, in the healthcare as spiritual care or clinical pastoral care. ${ }^{35)}$ This was partially influenced by the proposal, submitted between 1998 and 1999, to revise the "definition of health" by including the aspect of spirituality in the preamble to the World Health Organization's Charter. ${ }^{36}$

The Catholic Church, in the Second Vatican Council in the 1960s as well as the Synod of Bishops in 1987, recognized the universality of spirituality for all baptized Catholics including the laity, and emphasized the necessity to integrate spirituality with the daily lives. ${ }^{37)}$ The Church also recognized the increasing individuality of spirituality as the threat, and importance to foster the community based on spirituality. ${ }^{38}$

In the 1990s, Theological studies of spirituality increased. McGrath and Kaneko, in the definition of spirituality, both emphasize practicing it in everyday lives. ${ }^{39)}$

The first edition of "Encyclopedia of Religion" edited by Mircea Eliade in 1987 carries only "Christian spirituality," however, the second edition in 2005 carries "spirituality" as an independent word. ${ }^{40)}$

\subsection{Development of spirituality in Hong Kong}

Before Vatican II of the 1960s, spirituality of the laity in Hong Kong was based on devotion, penance, and prayer, and not on bible reading and liturgy which was conducted in Latin and not understandable. ${ }^{41)}$ Vatican II acknowledged the common holiness of all the believers and brought liturgical renewal. Such changes induced the laity to search for inculturated new spirituality unique to the laity and also to each person. Orientally inculturated spirituality, combined with Zen, Taichi or ecology, became popular. Vatican II also taught Catholics to be socially and politically concerned. ${ }^{42)}$ The laity were encouraged to put them into practice in their daily lives. Thus, a number of lay organizations with unique spirituality flourished. Social and political concern of Hong Kong Catholics were specially raised because of the handover of Hong Kong to China.

The Diocese of Hong Kong held the Diocesan Synod from 2000 to 2001. ${ }^{43)}$ Dominic Chan as the Vicar General was the Ex-officio Vice Chairperson and Moderator of the Synod.

The Diocesan Synod emphasized the necessities of integration of faith and daily lives of the Hong Kong Catholics and formation of faith communities at personal, parish and diocesan levels. Such recognition is the same as in Vatican II and Synod of Bishops as explained above. For example, the Diocesan Synod document recognized that "the foundation of sanctify is the integration of faith and daily living." ${ }^{44)}$ However, it analyzed the situation as that "most [lay] formation courses also seem to emphasize the knowledge of the faith but less weight is put on the integration of faith and Christian living or the mission of building up Christian communities, on the other hand, many faithful are not interested in the formation of one's spiritual life," "[some of the faithful] do not participate in the community life of the Church, rendering their faith irrelevant to their daily experience," and "Emptiness in heart and spirit is a basic cause of many personal and social problems in Hong Kong." ${ }^{\left.{ }^{45}\right)}$ The Document also recognized that "the ministry of the faithful in the Church is mostly task-oriented, ...lacking the energy to deepen their faith." ${ }^{46)}$

The Diocese, in order to implement the resolution on laity formation as suggested in the Diocesan Synod, further set the year 2011 to 2012 as the Year of the Laity. ${ }^{47)}$ This was because the Diocese was concerned about the low quality of the spiritual lives and individualism of the laity still observed in the recent years. ${ }^{48}$

\subsection{Preceding initiatives by Paul Tam and others}

Catholic engineers' association, initiated by Paul Tam, J. Chan, Raymond Shiu, and M.T. Chow, set the precedence of the CaBPAG. The association was originally planned for a practical purpose, but the members had spiritual concern.

Tam was a civil engineer who specialized in construction management, and lectured on it at the University of Hong Kong from 1995 to $2000 .{ }^{49)} \mathrm{He}$ was occasionally asked for advice by the Diocese on the maintenance of the diocesan cemeteries and church buildings. In the late 1990s, he conceived an idea to establish a Catholic engineers' association because he perceived that the professional laity in Hong Kong were always busy and had no opportunities to talk about the faith, yet, they should have more opportunities and time for spiritual activities. ${ }^{50)}$ Tam invited four other engineers, M.T. Chow and two more of the same parish, and Raymond Shiu of another parish, and began the discussion on what kind of association would be ideal. J. Chan was invited a short time later.

In 2000, Tam decided to become a priest and entered the Seminary, hence, could not maintain his leadership role in the association. He was ordained in 2008 as a diocesan priest.

J. Chan was Chief Structural Engineer of the Building Department of the Hong Kong Government. He was a member of the Cathedral Repair Committee, and was also involved in the Parish Council and other parish associations. ${ }^{51)}$

Raymond Shiu was a civil engineer of the Hong Kong Government. He was the chairperson of the Repair Committee of Rosary Church, and took care of the major renovation in the past. ${ }^{52)} \mathrm{He}$ was not a DBDC member, but was the RDC member since January, 2004. ${ }^{53)} \mathrm{He}$ was the only one who had a direct connection with the DBDC among the six initiators of the association.

M.T. Chow was also a civil engineer and a colleague of R. Shiu. ${ }^{54)}$

\section{$3.43 \mathrm{~S}$ as the CaBPAG's mission}

As explained in 2.4, spirituality as one of the main objectives was proposed by D. Chan during the initial discussion on the association at the RDC. The lay members favored it and gradually materialized through discussions.

First, when the RDC began planning the engineers' association, Shiu took the responsibility to draft the objectives and presented them in the RDC meeting on June $3^{\text {rd }}$, 2005, as "Initial Proposal to form an Association of Catholic Engineers," in which he defined the primary purpose of the activities to "improve the spiritual life and fellowship of members."."55)

Then, Gabriel Lam, being inspired by Simon Li, the DBDC chairperson, defined "3S"(services, sharing, sanctification) in the draft "Statement of the Objectives" submitted to the Preparatory Committee in early August 2005. ${ }^{56)}$ According to the meeting minutes on September 5, 2005, the following draft by Lam was approved. ${ }^{57)}$ :

\section{Statement of Objectives}

The objectives of the Association can be described by 3S: 
(a) Services- With the experiences and talents God has granted us, we shall provide voluntary professional engineering and related advice to parishes, deaneries and the Diocesan. These may include professional advice on church maintenance and renovation work, compliance with relevant government regulations, societal issues, etc.

We shall work hard to deliver one more talent even if we were given only one. (Matthew 25:14 - 30; Luke 19:11 - 27)

(b) Sharing- We are living in a secular world and consistently facing challenges to our faith. Through fellowship sharing and recreational activities, we shall offer mutual support and enlightenment, opportunities for personal growth and relaxation from work pressures.

We shall strive to be as wise as a serpent, and as simple as a dove. (Matthew 10:16)

(c) Sanctification- Through our services to and experience sharing with other church groups and community at large, we shall ultimately sanctify ourselves and others, hence spreading the Good News of the Bible.

We shall aim to make the Church more visible and become the salt and light of the world. (Matthew 5: 13 -16; Luke 14:34)

$3 \mathrm{~S}$ as "services," "sharing," and "sanctification" are used 10, 10, and 12 times respectively in the "Decree on the Apostolate of Laity," one of the Vatican II documents in 1965. ${ }^{* 11}$ Three terms are also used 91, 44, and 13 times respectively in the "Post Synodal Apostolic Exhortation: Christifideles Laici" published as the result of the 1987 Synod. ${ }^{\left.{ }^{122}\right)}$ "Sanctification" and "sharing" appear frequently in the Hong Kong Diocesan Synod documents. Further, concrete actions suggested in the Year of Laity included keywords of "sanctification," "share," and "spiritual growth."

On the basis of Lam's writing, Dominic Chan revised it several times to be incorporated in the CaBPAG's "Working Guidelines for Members" first drafted in 2006(see 2.7) ${ }^{59)}$ In the officially published guidelines in 2011, the objectives remains unchanged except a few words. ${ }^{60)}$

The draft Working Guideline of 2006 carries as follows: ${ }^{61}$

Missions and Objectives

CaBPAG is set up with a view to pool volunteers to provide professional advice to the Church on building related matters. The objective is to enrich our spiritual life and fellowship for inner sanctification through services, workshops, retreats, sharing and pilgrimages, so as to achieve the following 3 ' $\mathrm{S}$ ' key mission: to serve, share and sanctify.

Statement of Objectives

(a) Services - To enshrine our Catholic spirit and make the Church more visible through serving with our gifted talents and potential.

'We shall aim to make the Church more visible and become the salt and light of the world.' (Matthew 5:13-16)

(b) Sharing - It is only through fellowship sharing and recreation pursuits could we face challenges to our Catholic faith, offer mutual support in personal growth and enlightenment, search relief from daily pressures and rediscover our inner self.
'And be thankful. Christ's message in all its richness must live in your hearts. Teach and instruct one another with all wisdom.' (Colossians $3: 15-16)$

(c) Sanctification - Through serving the church and experience sharing, we shall sanctify and transform ourselves to answer the divine call and spread the Good News.

'And for their sake I consecrate myself, that they also may be consecrated in truth.' (John 17:19)

The paragraph of "Missions and Objectives" uses Shiu's writing of "spiritual life and fellowship."

In Lam's draft, he used the specific terms such as "professional engineering and related advice," "church maintenance and renovation work, compliance with relevant government regulations, societal issues," which were replaced in the 2006 draft guidelines by more general and non-specific expressions.

Regarding "sharing," Lam's main idea is respected in the $2006 \mathrm{draft}$ guidelines.

With regards to "sanctification," Lam's idea to achieve sanctification through services and sharing is inherited in the 2006 draft guidelines, which added "answer divine call" for the enhancement.

Lam supplemented 3S with bible scripts from "Matthew." He explains that the bible scripts he originally proposed for the $3 \mathrm{~S}$ had been always close to his heart. In the $2006 \mathrm{draft}$ guidelines, though one script of "the salt and light of the world" is maintained, the other two scripts were replaced by those from other books.

In the 2006 draft guidelines, Shiu's spirituality and Lam's 3S missions were integrated, wordings were improved, and bible scripts were replaced by more suitable ones. Lam's idea was not refused but rather enhanced. In other words, the laity's spirituality was recognized by the Diocese as the mission of the new organization.

\subsection{The Patron Saint}

Several laity members proposed the patron saint for the CaBPAG including Saint Joseph, the carpenter and foster father of Jesus. ${ }^{62)}$ Finally, St. Francis of Assisi, proposed by Dominic Chan, was chosen because of his lifetime dedication to building and prospering the church as well as his talented mastery and innovative design in the construction of church building. ${ }^{63)}$ This was accepted by the CaBPAG members as they felt this would reflect the same call that drew them together. ${ }^{64)}$

The DBDC also adopted St. Francis of Assisi as its patron saint in 2010. ${ }^{65)}$ 3.6 Integration of profession and spirituality in Spiritual Team

Spiritual Team was established in 2008, and its objective is to promote the $3 \mathrm{~S}$ and to enrich spiritual life and fellowship of members through workshops, retreats, sharing and pilgrimage visits. ${ }^{66)}$ This Team's aim was to integrate profession and spirituality.

The members of the Team were not satisfied with the professional development only. For example, J. Chan says that there are already a number of seminars for professional development organized by the professional and academic institutions in Hong Kong, hence, it is not meaningful and attractive if the CaBPAG organizes similar ones. Rather, it should emphasize spirituality and faith aspects. Furthermore, he believes that when the 
importance is placed on 3S, people will stay with the Church. ${ }^{67)}$

In addition, they were not satisfied with spirituality only. They conducted a questionnaire survey to the CaBPAG members in April and May, 2008 prior to the official start-up of the Team to collect their view on the long-term spiritual program. The Team members observed from the questionnaire that "most members would likely have their spiritual activities with other Church groups." Therefore, the Team decided to integrate the spiritual activities and professional activities, and to "explore the possibility of having seminars in which experienced professionals can share their professional experiences integrated with spiritual searching." ${ }^{68)}$

\subsection{The role of Spiritual Team in the CaBPAG}

The spiritual activities are interrelated with building and maintenance activities of other teams, and the Team is not isolated from other teams. This is illustrated in table 1: all the Spiritual Team members belong to one or more of the other teams. More than half of the present Spiritual Team members have participated in parish advisory teams of either the Hong Kong Team or the Kowloon and New Territories Team and belong to the Cemetery Team as well. The BSE Team gave seminars of "Sign of the Time: Environmental Protection" and "Energy efficiency: a Stewardship of God's Creations" in collaboration with the Spiritual Team.

As table 1 also shows, Paul Tam is a member-cum-adviser of the Spiritual Team and played the role of the speaker four times since becoming an ordained priest. He also belongs to the Cemetery Team.

J. Chan's activities are also diverse and interrelated within the CaBPAG. He has been the member of the Spiritual Team since its establishment in 2008. He became the Convenor of the CaBPAG officially in 2009, and has been coordinating all the CaBPAG activities. He retired from the Government in 2010 and took on more responsibilities for the CaBPAG. Table 1 shows that, as the leader of the Hong Kong Team, he coordinates all the parish projects, forms the parish advisory teams, and monitors the projects.

Gabriel Lam is by profession an energy and environmental consultant, and was previously Study Manager for the potential application of renewable energy in Hong Kong for Electrical and Mechanical Services Department of the Hong Kong Government. ${ }^{69)}$ He was one of key persons to establish the CaBPAG in the preparatory stage by defining $3 \mathrm{~S}$ missions (see 3.4). Further, he planned and organized the spiritual activities from 2006 to 2012 as the leader of the Special Duties Team, which was the predecessor of the Spiritual Team, and as its first leader until 2012 (table 1). Lam resigned as the Team leader because he became involved more in the BSE Team projects. Another reason was his belief that he should not stay in a key position for too long. ${ }^{70)}$ However, he remains a Team member, and also belongs to the Cemetery Team in addition to the BSE Team. As the BSE Team member, he participated in a project to install renewable energy at St. Raphael's Cemetery. Lam says that the BSE Team is particularly suited to his specialization. He has thus been assisting in the energy and carbon audits, and energy efficient lighting work. He organized the seminar "Energy efficiency: a Stewardship of God's Creations" in February, 2011 as a collaboration between the BSE Team and the Spiritual Team (table 1). He also joined the parish advisory team for St. Jude's Church, where he was a parishioner. After the parish advisory team was dissolved, he continued to assist the parish as a member of the parish maintenance committee. ${ }^{71)}$

P. Kwong is the second leader of the Spiritual Team, and is a civil and structural engineer specialized in project management in the private sector (table 1). ${ }^{72)}$ He became a CaBPAG member in 2009 by his friend's invitation. He retired in 2010. After that, he enrolled in the Bachelor of Sacred Theology course at Holy Spirit Seminary College of Theology and Philosophy, and has a great interest in spirituality and theology. He also joined the parish advisory teams of Mother of Good Counsel and St. Francis of Assisi (table 1). In 2012, he accepted the leader's position of the Spiritual Team.

The members of the Spiritual Team increased to eight in 2012 (table 1). ${ }^{73)}$ Since then, the Team holds two kinds of activities:

One is the monthly meeting for Team members, in which one of them prepares the topic, for example, the Pope's apostolic letter, professional ethics etc., to discuss it and share their thoughts.

The other is public events to be held a few times in a year for all CaBPAG members. As table 1 shows, the themes of the public events are wideranged from architectural design and the aesthetics of churches, government regulations on buildings, corporate social responsibilities to environmental protection and faith. The number of participants in each event ranges from 15 to 50. There are some members, who joined the CaBPAG through those public events. ${ }^{74}$

It is indicated that the integration of building profession and spirituality is also realized in members' meeting and the public events.

The new members of the Spiritual Team also participate in multiple teams: L.H. joined the parish advisory team of Mother of Good Counsel and St. Francis of Assisi. A.M. belongs to the Cemetery Team and also the Steering Group. Pete joins the Cemetery Team. CM was not a member of the CaBPAG's parish advisory team for St. Mary's Parish, to which he belongs, but the member of St. Mary's Parish Premises Committee.

\section{Interpreting the CaBPAG and its Spirituality in Social Contexts}

The authors pointed out three contexts to interpret the laity involvement in Hong Kong in Chapter 1 and the previous study. This study indicates that the CaBPAG and its spirituality can be understood as follows:

The endangered religious freedom anticipated by the handover of Hong Kong to China brought about the establishment of the DBDC as well as the CaBPAG, and the involvement of the laity. As explained in 3.2, the pursuit of new and unique spirituality as well as social concern prevailed among the laity in Hong Kong after Vatican II, and were further urged by the handover issue. As described in the CaBPAG's "Statement of Objectives," the laity perceived "challenges to our Catholic faith." It illustrates that this social concern is one of the causal agents of the pursuit of spirituality integrated with the building and maintenance activities, which were indeed unique to building professionals. This phenomena is worth much attention from the perspectives of both religious study and religious architectural study.

Regarding the identity issue, the laity of Hong Kong seemed to have been searching and trying to establish their Catholic identity, not as an individual but as a communal one. This corresponds with spirituality of the Catholic Church in recent decades. CaBPAG fosters such a communal identity. 
As to the matured society, it is not only observed in the fact that there are a number of professional laity, but also more significantly, the laity themselves played the significant role in shaping spiritual activities, and defined the " $3 \mathrm{~S}$ " mission.

\section{Conclusions}

The CaBPAG was established in 2006 under Diocesan Building and Development Commission set up in 1995.

The objective of the CaBPAG is to assist by the professional laity in parish and diocesan building and maintenance projects, which only under the DBDC became unsustainable by the early 21 st century. The CaBPAG members work between the Diocese and parishes with great flexibility. For the Diocese, they assist in the cemeteries and building services. For the parishes, they support maintenance, major renovation and extension.

This study revealed that the activities of the CaBPAG are based on spirituality and they were mostly shaped by the laity. The laity designed the CaBPAG as their place for the spiritual activities. For example, they found it meaningful to form a community of the building professionals for the purpose of the spiritual activities, and defined " $3 \mathrm{~S}$ " (services, sharing, sanctification) as the CaBPAG's mission. They set up the Spiritual Team, and also collaborate with or simultaneously join other teams such as parish advisory teams, the Cemetery Team, and the Building Services Engineering Team. These two types of activities, spiritual growth and professional advice, are interrelated and integrated.

The background of such spirituality of the CaBPAG can be understood within the following two contexts: one is worldwide emergence and development of spirituality since the 1960s in and outside of the Catholic Church along with accelerated laity involvement in Church management as the authors pointed out in a previous study. The other is the local contexts of Hong Kong such as the endangered religious freedom, identity search, and matured society. These two backgrounds interrelate to a certain extent.

This study illustrates that the laity involvement in building projects in the Catholic Diocese of Hong Kong is not just the mobilization of their professional and technical abilities, but more importantly, the integration of their spirituality with their professions and fostering the communal faith as their own initiative.

\section{References}

*1) Bacik, James J.: Catholic Spirituality, Its History and Challenge, Paulist Press, 2002.

*2) Catholic Building Professional Advisory Group: Confirmed Notes of Steering Group/Committee Meeting. DBDC Office, Catholic Diocese of Hong Kong.

*3) Diocesan Building and Development Commission: Minutes of Meeting. DBDC Office, Catholic Diocese of Hong Kong.

*4) Fukushima, Ayako: Catholic Laity Involvement In Church Building Project, Management of church building projects in the Hong Kong Catholic Diocese from the 1960s to present, Journal of Architecture and Building Science, 76, No.667, pp.1711-1719, 2011.9

*5) Fukushima, Ayako and Yoshitake Doi: The Building Process and the Laity Involvement of Our Lady of Mount Carmel Church in Wanchai, Hong Kong: Church building system of the Catholic Diocese of Hong Kong, Journal of Architecture and Building Science, No.688, pp. 1431-40, 2013.6

*6) McGrath, Alister E.: Christian Spirituality: An Introduction, Wiley-Blackwell, 1999.

*7) Leung, Beatrice.: Political Participation of the Catholic Church in Hong Kong
SAR, New Trends of Political Participation in Hong Kong, City University of Hong Kong Press, pp.285-310, 2014

*8) Research and Development Committee: Minutes of Meeting. DBDC Office, Catholic Diocese of Hong Kong.

*9) The Canon Law Society Trust: The Code of Canon Law, Paulines, 1983.

*10) The Holy See: "DOGMATIC CONSTITUTION ON THE CHURCH: LUMEN GENTIUM." 1964, accessed July 1, 2013, http://www.vatican.va/archive/hist_ councils/ii_vatican_council/documents/vat-ii_const_19641121_lumen-gentium_ en.html.

*11) The Holy See: "DECREE ON THE APOSTOLATE OF THE LAITY: APOSTOLICAM ACTUOSITATEM.” Pope Paul VI. 1965. accessed July 1, 2013, http://www.vatican.va/archive/hist_councils/ii_vatican_council/documents/vat-ii_ decree_19651118_apostolicam-actuositatem_en.html.

*12) The Holy See: "Post-Synodal Apostolic Exhortation: Christifideles Laici." Pope John Paul II. 1988. accessed July 1, 2013, http://www.vatican.va/holy_father/john_ paul_ii/apost_exhortations/documents/hf_jp-ii_exh_30121988_christifideles-laici_ en.html.

\section{Notes}

1) Vatican II Document "DECREE ON THE APOSTOLATE OF THE LAITY" uses the term "lay apostolate." "Lay ministry/lay minister" seems to have been popularized by the publication of United States Catholic Conference's, "Called and Gifted: The American Catholic Laity" (1998, first printing 1980). "Lay ministry" have apparently prevailed worldwide by the 1990s.; Donna S. Eschenauer and Harold D. Horell, eds.: Reflections on Renewal: Lay Ecclesial Ministry and the Church. Liturgical Press, 2011.

2) $* 4$.

3) $* 5$.

4) Details of three contexts are as follows:

Context 1 needs to be understood in the following five backgrounds:

1-1. Church-state relations and the status of religious property in Hong Kong during the colonial period until 1997.

Church-state relations had been "contractual relationship" in which they closely collaborated especially in social welfare services $(* 5)$. Since the 1950 s, the Church had built and operated many schools, which usually embedded parish churches and priest quarters, or whose halls were utilized as churches during weekends. Most of those schools have been subsidized by the government (*7; Edward Khong, email message to author, 10 September 2014.).

1-2. Church-state relations in mainland China until 1997.

The status of religion in mainland China has always been under suppression or persecution, which were well known by the Hong Kong Church. Until 1949, the Catholic Church relied upon its rentals from real estate, which the Church owned for financial self-support. Since the communist takeover in 1949, the Catholic resistance movement was met with condemnations and sweeping arrests of the clergy, religious and lay. The different government departments and organizations occupied a large number of the Church's real estate. In 1951, China broke off diplomatic relations with the Vatican. Since 1956 to present, the Catholic Church in China has been split into government-registered "Chinese Catholic Patriotic Association" and nonregistered "underground Church." During the Cultural Revolution from 1966 to 76, religion was banned. Further confiscation of Church estate was carried out. In 1978, China started to adopt the Open Door Policy. The Chinese state relaxed the ban on religious belief and practice, but exercised elaborate control over religious belief and organizations. In 1980, the State Council announced to return the occupied premises to the Church. Though most of church buildings have been returned, since 1989 the government was no longer going to return schools and other social welfare services facilities to the Church because the government could not afford compensating all the religious properties (Anthony S.K. Lam: Power and Struggle, Holy Spirit Study Centre, 2006, pp.69-88,; Kin Sheung Chiaretto Yan: Evangelization in China: challenges and prospects, Orbis Books, 2014, pp.23-70.; David Aikman: Jesus in Beijing, Regnery, 2006, p296, pp.303-304.).

1-3-1. Situation of the Church after the handover anticipated by the Hong Kong Diocese.

Since the 1980s, facing the handover of Hong Kong to China in 1997 and political shift under China, the Diocese anticipated "state domination of church," in which the new church buildings might not be allowed to be built, and school buildings might be confiscated by the government and not be allowed for religious use. Such fear had been shared not only among the clergy but also the laity $(* 5$; *7; Mary M.Y. Yuen: 
The Catholic Church in Political Transition, The Other Hong Kong Report 1997, ed. By Joseph Y.S. Cheng, the Chinese University Press, 1997, pp.503-528.; Interview with clergies by the author, Hong Kong, August and September 2014. These interviews were conducted confidentially, and the names of interviewee are withheld by mutual agreement.).

1-3-2. Hong Kong Diocese's concern about the future of economy and the property market.

On the other hand, since the 1960s, there had been rapid urban development in Hong Kong, and since the 1980 s urban redevelopment, which was accelerated by the handover issue. Hong Kong, Kowloon and the New Territories had been particularly growing fast and the new public housing as well as those of the private sectors came up fast in all areas. All the more, land supply was decreasing rapidly. Land, labour and material costs soared $(* 5$; Barrie Shelton, Justyna Karakiewicz and Thomas Kvan: The Making of Hong Kong, From Vertical to Volumetric, Routledge, 2010.; Edward Khong, 10 September 2014.). Meanwhile, for the Diocese, it has always been a policy to provide places of worship as an evangelization and pastoral services to the community as long as it was affordable. With rapid urban development as well as unpredictable situation after 1997, if the Church did not foresee the situation of development, it would have no chance at all to acquire sites for the construction of churches. For this reason, the Diocese launched a joint redevelopment project with a developer to generate enough funds to build new churches, which were not combined with subsidized schools, and rebuilding/repairing existing ones without depending on the "contractual relationship" with the government (*5; Edward Khong, 10 September 2014.).

1-4. status of religion in China after 1997

In terms of freedom of worship for China's Christians, conditions have deteriorated as the Communist Party has tightened its grip. Since the Falun Gong spiritual movement in 1999, repressive actions against underground Catholic Church have greatly increased (Aikman: Jesus in Beijing, Regnery, p296, pp.303-304.).

1-5. status of religion in Hong Kong after 1997.

The society has been seeing the gradual "mainlandization." Church-state relations became antagonistic (*7). Between 1997 and 2014, the Catholic Church fought against implementation of Article 23 of the Basic Law, educational reform, Moral and National Education Curriculum, and limitation to universal suffrage, all imposed by the government and would undermine human dignity and religious freedom.;

Context 2. Search for Hong Kong identity emerged since the 1980s in relation to the handover. It can be assumed that Hong Kong Catholics searched for their Catholic identity through being involved in the church building projects.;

Context 3. By the 1980s, the professionals, who received higher education in Hong Kong, matured and began to contribute professionally to the Church. This was also the Diocese's decision to shift the building project management to the governance approach.

5) Simon Li, interview by the author, Hong Kong, 17 September 2012.

6) Tony Wong, interview by the author, Hong Kong, 28 September 2012; Catholic Truth Society: Hong Kong Catholic Directory 2013, Catholic Truth Society, 2012. The Catholic population of the Diocese as of 2012 was 368,000. Parishes were 51, and the places for religious churches including churches, chapels, and halls were 97.

7) DBDC: Effective Management Operation Model for Parishes (workshop, the Catholic Diocese of Hong Kong, Hong Kong, 4-6 January 2005).

8) *8. Day 1, 4th Jan 2005, Session 1B Building Maintenance and Management, Session 2 Building maintenance and renovation, Appendix, No. 51, 5 February 2005.

9) Simon Li: Catholic Building Advisory Group, (Appendix of RDC MM No. 54, 2005 October); *3. Simon Li and VG Fr. Dominic Chan: Catholic Building Professional Advisory Group, folder, EMOM-DBDC(05)/, November 2005.; J. Chan, interview by the authors, Hong Kong, 18 September 2012.

10) Diocesan Commission for the Health Care of The Clergy and Religious. (About us; accessed 1 July 2013). http://healthnews.catholic.org.hk/eng/index.html. The Commission oversees the Medical Support Scheme for the diocesan clergy and members of religious communities working in parishes of the Diocese as well as retired. Under this scheme, a voluntary team of one Catholic medical doctor and one Catholic nurse is assigned to each parish to provide health support and general medical advice to the clergy working there. These services were planned because the clergy and the Religious tended to neglect their own healthcare. The chairperson of the Commission is Dominic Chan, the Vicar General; Simon Li, interview by the author, Hong Kong, 17 September 2012. This was the first commission, which is composed of the professional laity to act as advisers.

11) J. Chan, email message to author, 7 June 2013.
12) *8. No. 51, 5 February 2005. Dominic Chan mentioned in the DBDC and the RDC meetings that "the contribution were appreciated by the priests [who participated in the WS], and with reference to the DBDC Meeting on 22 January 2005, it was suggested that DBDC can recruit some Catholic volunteers in the architectural, engineering, and building services fields to help in the Diocese and Deanery. They can become helpers to DBDC on tasks such as study on barrier free access, slopes and database on parishes."; Dominic Chan, phone interview by the author, 10 September 2014.

13) *8, No.51, 52, 53, 54, 55, 5 February 2005 - 15 October 2005. In the meeting minutes, various names appear such as Catholic Engineers' Association, Engineering Advisory Team, and Catholic Support Group of Building and Related Professionals.

14) *3. No.56, 5 March 2005 .

15) *8. No.53, 4 June 2005.; J. Chan, email massage to author, 10 June 2013. Gabriel Lam was invited to the committee, and asked to draft the association's statement of objectives based on spirituality.

16) for details, see 3.4; Diocesan Building and Development Commission(DBDC) Confirmed notes of 2nd Preparatory Committee Meeting of the Catholic Building Professional Advisory Group, 5 September 2005, DBDC MM folder.

17) *8. No. 58, Appendix II, 8 April 2006.

18) Gabriel Lam, email message to author, 1 July 2013.

19) CaBPAG: Working Guidelines for Members, 2011, DBDC Office (hereafter cited as Working Guidelines 2011).

20) Working Guidelines 2011.

21) see note 20 above.

22) J. Chan, interview by the authors, Hong Kong, 19 September 2012.

23) see note 20 above.

24) see note 20 above.

25) see note 22 above.

26) see note 22 above.

27) Tony Wong, interview by the author, Hong Kong, 28 September 2012.

28) Leung Kingwai, interview by the author, Hong Kong, 5 October 2012.

29) see note 11 above.

30) J. Chan, email message to author, 10 June 2013.

$31) * 3$. No.89, 4 September 2010 .

32)*2. 18 April 2012; J. Chan, interview by the author, Hong Kong, 28 March 2013.

$33) * 6$, pp.1-7. "The word 'spirituality' draws on the Hebrew word ruach, a term usually translated as 'spirit.' 'Mystical' had been used to refer to the spiritual dimension of theology since the sixth century. The modern terms 'spirituality' and 'mysticism' both trace their origins back to seventeenth century France, and specifically in the rather elitist circles of salon society. Two terms were used to refer to direct interior knowledge of the divine or supernatural, and were apparently treated as synonymous at the time. 'Mysticism' has been gradually displaced by 'spirituality.'; Charles E. Curran: The Catholic Moral Tradition Today: A Synthesis. Georgetown University Press, 1999, p93. "Traditional spiritual theology often emphasized religious life and priesthood as the primary locus of spirituality. ... Spirituality seemed to call people away from their relationships with family, neighbor, and world into a life that was withdrawn from others and concerned on God alone. The Second Vatican Council recognized that the gospel call to holiness is universal; it is directed to all the disciples of Jesus, and it is rooted in our baptismal commitment."

34) Susumu Shimazono: Supirichuarithi no Kouryu スピリチュアリティの興 隆 [Emergence of Spirituality], Iwanami Shoten, 2007, pp.27-28, 48-60; Susumu Shimazono: Nihon no sezokuka to atarashii supirichuarithi: shukyou shakaigaku to hikaku bunka • hikaku bunmei no shiza 日本の世俗化と新しいスピリチュアリ ティ：宗教社会学と比較文化・比較文明の視座 [Secularization in Japan and new spirituality: sociology of religion and the perspective of comparative culture and civilization], 社会志林 Shakai Shirin 57(4), 23-34, 2011, p49.

35) A. Weaver, K. Flannelly, and J. Oppenheimer: Religion, Spirituality, and Chaplains in the Biomedical Literature: 1965-2000, International Journal of Psychiatry In Medicine, 33(2), 2003, pp.155-161.

36) Masako Nagase: Does a Multi-Dimensional Concept of Health Include Spirituality? Analysis of Japan Health Science Council's Discussions on WHO's 'Definition of Health' (1998), International Journal of Applied Sociology, 2(6), 2012, pp.71-77.

37) *11. 2, 4, 5; *1, pp.40-41.; *9, p59. "Can 342. The synod of Bishops is a group of Bishops selected from different parts of the world, who meet together at specified times to promote the close relationship between the Roman Pontiff and the Bishops. These Bishops, by their counsel, assist the Roman Pontiff in the defense and development of faith and morals and in the preservation and strengthening of 
ecclesiastical discipline. They also consider questions concerning the mission of the Church in the world."

38) *11. Introduction, "This apostolate becomes more imperative in view of the fact that many areas of human life have become increasingly autonomous. This is as it should be, but it sometimes involves a degree of departure from the ethical and religious order and a serious danger to Christian life."; PASTORAL CONSTITUTION ON THE CHURCH IN THE MODERN WORLD: GAUDIUM ET SPES, 1965. 43, http://www.vatican.va/archive/hist_councils/ii_vatican_council/documents/vatii_cons_19651207_gaudium-et-spes_en.html.; AD GENTES: DECREE ON THE MISSION ACTIVITY OF THE CHURCH, 21, http://www.vatican.va/archive/hist_ councils/ii_vatican_council/documents/vat-ii_decree_19651207_ad-gentes_en.html; *12. 17, 59, 1988; *1, p45. In the West, by the 1980s, individualism or privatization among Catholics was recognized as an accelerated threat. Individualistic spirituality, emphasizing Catholics' personal relationship with God became the main stream, whereas, communal spirituality that focuses on the achievement of a peaceful and just social order and integrated spirituality that combines both individualistic and communal values became unpopular.

39) *6. pp.1-3. "Christian Spirituality concerns the quest for a fulfilled and authentic Christian existence, involving the bringing together of the fundamental ideas of Christianity and the whole experience of living on the basis of and within the scope of the Christian faith. It is also the way in which Christian individuals or groups aim to deepen their experience of God, or to practise the presence of God. 'Spirituality' is about the life of faith - what drives and motivates it, and what people find helpful in sustaining and developing it. It is about that which animates the life of believers, and urges them on to deepen and perfect what has at present only been begun. Spirituality is the outworking in real life of a person's religious faith - what a person does with what they believe. It is not just about ideas... It is about the way in which the Christian life is conceived and lived out.”; Haruo Kaneko: Kirisuto Kyou Reisei Sisou Shi キリスト教霊性思想史 [History of Christian Spirituality], Kyoubunkan, 2012, p553, p555. "Spirituality is to 'deepen inward and at the same time practice outward, 'in other words, enriched spirituality becomes the sources of the welldetermined practices."

40) The Encyclopedia of Religion, 2nd ed. comp. Lindsay Jones (Macmillan Library Reference, 2005), s.v. "spirituality."

41) Givanni Giampietro, interview by the author, Hong Kong, 27 August and 3 and 9 September 2014.

42) *7; Louis Ha, interview by the author, Hong Kong, 8 September 2014

43) *9, p82. Can. 460. "The diocesan synod is an assembly of selected priests and other members of Christ's faithful of a particular Church which, for the good of the whole diocesan community, assists the diocesan Bishop."

44) Catholic Diocese of Hong Kong: Catholic Diocese of Hong Kong Diocesan Synod Documents Group One Faith Formation of the Laity and Lay Ministry, The Secretariat of the Diocesan Synod, Diocesan Synod, p3, 30 December 2001.

45) Hong Kong Diocesan Synod Documents, p4, 5, 16.

46) Hong Kong Diocesan Synod Documents, p8.

47) Vicar General's Office: Theme of the Year of Laity, accessed 4 September 2013, http://vgoffice.catholic.org.hk/eng_main.html. The subtitle of the Year of the Laity was "Responding to the call of God and fulfilling the ministry of the laity," and Objective was "Living the joy of the lay life, building community spirit, being part of God's mission."

48) Vicar General's Office: 天主教香港教区 2010 教友信仰生活現況調査, accessed 2 July 2013, http://vgoffice.catholic.org.hk/chi_main.html. A survey conducted for the diocese's Year of the Laity Preparatory Committee shows that the fast pace of modern life is taking its toll on faith growth of local Catholics. For example, more than half of the respondents $-\mathbf{5 5 . 8}$ percent - did not join any laity groups. Very few Catholics read the bible, prayed or made confession regularly because of being too busy.

49) Paul Tam, interview by the author, Hong Kong, 19 September 2012.

50) Paul Tam, interview by the author, Hong Kong, 19 September 2012; J. Chan, interview by the author, Hong Kong, 18 September 2012.

51) J. Chan, interview by the author, Hong Kong, 18 September 2012.

52) J. Chan, email message to author, 30 June 2013.

53) *8. No.45, 31 January 2004.

54) J. Chan, email message to author, 14 September 2013.

55) RDC: Initial Proposal to form an Association of Catholic Engineers, 3 June 2005, RDC MM folder.

56) *3. No.59, 3 September 2005.; Diocesan Building and Development
Commission(DBDC) Confirmed notes of 2nd Preparatory Committee Meeting of the Catholic Building Professional Advisory Group, 5 September 2005, DBDC MM folder.; Gabriel Lam, email message to author, 1 July 2013.; J. Chan, email message to author, 7 June 2013.

57) Diocesan Building and Development Commission(DBDC) Confirmed notes of 2nd Preparatory Committee Meeting of the Catholic Building Professional Advisory Group, 5 September 2005, DBDC MM folder.

58) Dominic Chan, V.G.: Concrete actions suggested in the Year of the Laity in 2012, 1 November 2011, http://vgoffice.catholic.org.hk/eng_main.html.

59) *2. Appendix, No.1, 17 August 2006.

60) An Introduction on the Catholic Building Professional Advisory Group, Appendix of DBDC Draft Notes of 3rd Preparatory Committee Meeting of the Catholic Building Professional Advisory Group(CAP), 24 October 2005. In this draft, the statement was modified to include the overall introduction as "Here is Our Mission -3S."; CaBPAG website: Recruitment of Members of "Catholic Building Professional Advisory Group," accessed 5 September 2013, http://dbdc.catholic.org.hk/cabpag/index.htm. By the end of 2005 or early 2006, the two bible scripts for 3 S were replaced.

61) see note 59 above.

62) see note 18 above.

63) *8. No.56, 3 December 2005.

64) J. Chan, email message to author, 7 June 2013; American Catholic.org: Who Was St. Francis?, accessed 1 July 2013, https://www.americancatholic.org/features/francis/ who_was.asp.

$65) * 3$. No.86, 27 March 2010. Previously the DBDC did not have any patron saint.

66) *3. No.74, 15 March 2008.

67) J. Chan, interview by the author, Hong Kong, 1 April 2013.

68) CaBPAG: CaBPAG Newsletter to Members No.5, 2008 June, DBDC Office.; *3. No.77, 4 October 2008.

69) CaBPAG: CaBPAG Seminar on Energy efficiency-a stewardship of God's Creations, 26 February 2011, CaBPAG MM folder.

70) see note 18 above.

71) see note 18 above.

72) P. Kwong, email message to author, 21 June 2013.

73) P. Kwong, interview by the author, Hong Kong, 29 March 2013. About half of the Spiritual Team members are retired.

74) see note 51 above.

\section{和文要約}

「天主教建築專業諮詢小組 (Catholic Building Professional Advisory Group, $\mathrm{CaBPAG}) 」$ は、カトリック香港教区の建築及発展委 員会 (DBDC) の下部組織として、2006 年に設立された。直接的な設 立の要因は、小教区の営繥案件の増加と DBDC の人員不足であり、建 設分野のボランティア専門家集団によるアドバイスが主な活動であ る。しかし、CaBPAGの本来の目的は、同じ建設分野の専門家の信徒 同志が霊性を養う場として構想された。CaBPAG内では、小教区施設 や教区墓地営繕支援のチームとともに、霊性チームが設立された。 CaBPAG の特徵は、施設営䋨と霊性滋養を相互に関連して計画・実施 し、統合しているところにある。CaBPAG が信徒の霊性の場となった 背景には二つの流れが女る。一つは、1960 年代以降、カトリック教 会が第二バチカン公会議などにおいて信徒の霊性が聖職者と等しく あることを認め、重要視されるようになったことである。また同時 期にカトリック教会外では、「新霊性運動」などとも称される、既存 の宗教にとらわれない霊性が興隆した。二つめは、香港固有の文脈 である。1980 年代に決定した香港返還にともなって、香港の信者は 信仰の自由に対する危機意識を抱くようになった。この危機意識か ら、営繥活動のなかに霊性の実現をめざした。また、このような香 港の一般信徒は、霊性の希求というものをと扎して、カトリックと してのアイデンティティ、しかも個人ではなくコミュニティとして のそれ、をより確固としたものとしているといえる。さらに、信徒 
自らが霊性理念を構筑するという顕著な事実は、香港社会全体の成 熟の証左であるといえる。このようにカトリック香港教区における 営䌂への一般信徒参画の試みは、信徒の学識活用といった技術的レ ベルにとどまらず、彼らの自発的な霊性活動すなわち信仰として新 たな展開をみせている。

(2013年10月 8 日原稿受理, 2014年11月 6 日採用決定) 